\title{
Breeding biology of Southern Ground Hornbill Bucorvus leadbeateri in Zimbabwe: impacts of human activities
}

\author{
A. MSIMANGA
}

\section{Summary}

This paper summarizes current knowledge and outlines future work on the breeding biology of Southern Ground Hornbill Bucorvus leadbeateri in Zimbabwe. All available records since 1900 were analysed, including casual reports by members of BirdLife Zimbabwe and published records. Estimates were made for the start and end of the breeding season, group sizes, clutch size and productivity levels, together with an assessment of preferred habitats and nest-tree species. There is a need for intensive fieldwork to determine aspects of breeding biology such as incubation and nestling periods. Particularly important for sound management and conservation strategies is relative breeding success in different land-tenure systems. The author has started work in a communal area $40 \mathrm{~km}$ south of Bulawayo city; land-use systems such as new resettlement areas, commercial farms and protected areas remain to be studied.

\section{Introduction}

Southern Ground Hornbill Bucorvus leadbeateri is one of 43 protected species in Zimbabwe (Irwin 1981). It is sensitive to habitat disturbance and has been classified as Vulnerable in the South African Red Data Book (Brooke 1984, Kemp 2000a). It mainly occupies savanna habitat and agricultural lands (Kemp 1988, Kemp and Kemp 1980, Kemp et al. 1989, Maclean 1993, Reeson et al. 1994). In Zimbabwe, it occurs mostly in regions of low altitude and rainfall, the south, west and north-west of the country. The species is scarce in the Eastern Highlands where precipitation is generally higher (Chiweshe 1994, Hustler et al. 1990, Irwin 1981, Reeson et al. 1994). What little is known of its biology derives from work in Kruger National Park in neighbouring South Africa (Kemp 1987, 1988, 1994, 1995) and Kwazulu-Natal (Knight 1990). In Zimbabwe, no systematic work has been conducted on breeding biology but casual reports on breeding activities have been kept since the early 190os and were analysed for this study.

Like most large birds, Bucorvus leadbeateri is unevenly distributed at low densities, defends large territories (about $100 \mathrm{~km}^{2}$ ) and has widely spaced breeding sites (Kemp 1987, Kemp et al. 1989, Knight 1990). Further, it is the largest bird species that breeds cooperatively (Kemp 1988, Kemp and Kemp 1980) and the only hornbill that is entirely carnivorous (Kemp 1987, 1988, Kemp and Kemp 1980). These and other biological characteristics of B. leadbeateri render it vulnerable. In South Africa, Kemp (1987) found that the species had disappeared from parts of its former range in the north and east of the country due to direct 
persecution through shooting and poisoned baits. In Zimbabwe, however, decline was attributed primarily to habitat destruction (Chiweshe 1994, Msimanga 2000, Vernon and Herremans 1997). Loss of large hollow tree-trunks used for nesting is the major threat in settled unprotected areas, mainly the densely populated communal lands. Among local populations it is taboo to kill or persecute Southern Ground Hornbill, which is held sacred due to the belief that it is involved in rain-making (Msimanga 2000). The birds suffer direct persecution only at the hands of a few commercial farmers because the birds smash windowpanes as they attack their reflections on the glass (Chiweshe 1994).

The critical aspect of Southern Ground Hornbill breeding biology is low productivity. In South Africa, clutch size is one or two eggs, incubated for about 42 days. Usually only one egg hatches; when both eggs hatch, the younger nestling usually starves to death (Kemp 1976, Kemp and Kemp 1980). Fledging requires another 86 days, during which the adult female will feed her chick with assistance from other group members. It takes 6 years for a young bird to reach adulthood and many probably do not start breeding even then (Kemp 1987). Observations in South Africa show that on average one chick is reared to fledging every 9 years (Kemp, 1995).

Previous work in Zimbabwe included analyses of spatial distributions but not general ecology or breeding biology (Chiweshe 1994, Hustler et al. 1990, Vernon and Herremans 1997). This paper is the first step towards structured research on B. leadbeateri in Zimbabwe.

There is a clear need to understand Southern Ground Hornbill biology in Zimbabwe, to implement conservation and management plans for both the bird and its habitat. Kemp (1987) observed that due to the large territory defended by B. leadbeateri in South Africa there was a need to conserve vast areas of suitable habitat. This is likely to be the case in Zimbabwe as well and, as Chiweshe (1994) has already shown, there are important differences in distribution and density of birds in areas under different land-use systems. The land redistribution programme being implemented by the government of Zimbabwe has brought about rapid changes in landscapes. Current work by the author in a communal area will help determine more conclusively the anthropological and ecological factors affecting Southern Ground Hornbill breeding and conservation and formulate management strategies for conservation of hornbills in newly settled areas. This is critical because large tracts of land that were commercial farms and protected areas are being opened to more communal forms of management. It is important to come up with management strategies for avian species that can be understood and implemented by communal farmers.

\section{Methods}

Records of breeding sites of Southern Ground Hornbill were extracted from published and unpublished literature, primarily from the Nest Record Cards (NRCs). These are records of the breeding activities of birds in Zimbabwe, supplied by observers around the country since 1900. Details entered on the cards include dates of observation, geographic location, description of nest structure and site, description of contents and habitat. 
These data were supplemented by the author's personal observations of a family group of hornbills resident on communal lands some $40 \mathrm{~km}$ outside Bulawayo. This group has been studied irregularly for two breeding seasons, as part of the "Birds and Man" project of the Ornithology Department of the Natural History Museum of Zimbabwe. This group of hornbills will form one of four groups to be monitored more systematically over the next 5 years. I was able to locate and follow the group slowly, observing individual and group activities without disturbing them. Interviews were conducted with local communities to assess their knowledge of the biology of the birds and to determine cultural attitudes and beliefs that may affect the birds.

Further analyses of data determined average group sizes, clutch sizes, hatching and nestling success rates, nest location preferences, preferred nest-tree species and sizes, as well as incubation and nestling periods. Preferred months for the onset of laying and hatching were also determined.

\section{Results}

Information was available for 111 breeding attempts. Clutch size was one or two. About $65 \%$ of clutches consisted of two eggs and $33 \%$ of total breeding attempts hatched one or both eggs $(n=37)$. Only $21 \%$ produced a fledged young that left the nest $(n=23)$. However, these figures are very conservative as they derive from casual observations.

Initiation of breeding ranged from September to April, with most egg-laying occurring from September to December $(n=47)$. The same nest-holes were used in successive years. Information in 46 reports included tree species, the most common being Adansonia digitata $(28 \%, n=13)$, Acacia spp. $(15 \%, n=7)$, Colophospermum mopane $(13 \%, n=6)$ and Diospyros $(8 \%, n=4)$. Other trees used included Parinari, Julbermardia, Brachystegia, Ficus, Combretum, Kigelia, Afzelia and Baikeae spp., all reported once.

Nest-sites are open hollows in a dead or living tree-trunk. Unlike other hornbill species the hollow is not sealed, and although the female remained inside for most of the breeding season she did not undergo a complete moult. While most nests were placed $4-7 \mathrm{~m}$ up the tree-trunk, with a few as low as $1 \mathrm{~m}$ and some higher than $14 \mathrm{~m}(n=33)$.

The number of individuals in breeding groups ranged from three to six. Some groups used the same nest for over 10 years. However, groups as large as nine have been observed during non-breeding seasons (Chiweshe 1994). From available data it was not possible to determine productivity rates, but one nest which was monitored for five successive years produced only one independent young in that period.

Although Southern Ground Hornbill is a savanna bird, sight records exist for the more mesic highland habitats of Zimbabwe. In Nyanga, the highest area in Zimbabwe, parties of three birds have been observed in grasslands at about 1,675 m above sea level (a.s.l.) (Borrett 1967, Lorber 1982, Manson and Tree 1983). Similar reports of hornbills on montane grassland have been made in Malawi and Zambia on the Nyika plateau at 2,000 m a.s.1. (Benson and Benson 1977). 


\section{Discussion}

Breeding success of Southern Ground Hornbill in Zimbabwe seems to be comparable with that in neighbouring South Africa, characterized by low productivity, high survival rates of individual birds, sparse distributions and large territory size. Distribution reports suggest that, like its northern sibling species (Archer and Goodman 1961), B. leadbeateri is capable of existence in mild, moist conditions at high altitude, although data on relative abundance are unavailable. This may be important since, in Zimbabwe, large tracts of land in the highlands have been placed under the Department of National Parks and Wildlife Management but most savanna is owned either privately or communally. If most of the breeding occurs inside National Parks then the birds are relatively well conserved, but if there is significant breeding in communal lands or newly settled areas then community participation is essential for their conservation.

In the savanna habitats from which most breeding records have been collected, Southern Ground Hornbill favours cavities in Adansonia digitata, a large tree associated with sacred sites and rituals in most parts of western Zimbabwe. Probably because of its size and the high incidence of lightning strikes on tall trees it is linked with the revered "Lightning Bird". Traditionally, a tree that was once struck by lightning is held sacred as the "Lightning Bird" is supposed to have laid its eggs at the tree's bottom (Msimanga 2000). Its wood may not be used for fuel, fencing or building, the major uses of wood in communal lands. In some communities not even honey may be taken from such trees. However, other plant species favoured by Southern Ground Hornbill in Zimbabwe are not protected by traditional beliefs. In fact they provide preferred firewood, roofing and fencing material, especially Colophospermum, Combretum, Julbernardia and Brachystegia species. With increasing human populations in communal lands and the newly formed resettlement areas it is important to address the delicate balance between the need to meet survival requirements and conservation considerations by rural communities. Otherwise, threatened species may become restricted to protected land such as national parks and forest reserves. For species such Southern Ground Hornbill, whose range overlaps both protected and settled land, this may not be sufficient for their effective conservation. Hence there is a need to raise the level of awareness among the new communities, and also a need to conserve large areas of habitat.

There is also a need for a more focused, long-term study of Southern Ground Hornbill in Zimbabwe, particularly its breeding biology, ecology and distribution. These are essential to establish effective conservation strategies that will work both in settled as well as protected land. While Kemp (1987) observed in South Africa that direct and indirect persecution were the main factors for the disappearance of the species from many parts of the country, in Zimbabwe it is under threat more from habitat destruction than from persecution.

In South Africa a rehabilitation programme was introduced about a decade ago whereby the National Parks Board harvests the second chick for handrearing and reintroduction into the wild (Kemp 200ob), a programme which Zimbabwe could imitate. A comparison of group size in three different land-use types revealed that the largest number of Southern Ground Hornbill was inside National Parks (Chiweshe 1994) and that there were more juveniles among 
groups in National Parks than in communal land. More recently, however, groups have been sighted in communal lands accompanied by more than one juvenile (Magwizi 2000).

\section{Acknowledgements}

My attendance at the Third International Hornbill Workshop was made possible by financial assistance from the Hornbill Research Foundation. I thank Dr Pilai Poonswad and the Organising Committee of the workshop for inviting me to Thailand. National Museums and Monuments of Zimbabwe and the government of Zimbabwe granted permission for me to undertake the trip. I thank the various birders around Zimbabwe for making their data available, and in particular the local communities that I work with in Zimbabwe.

\section{References}

Archer, G. and Goodman, E. M. (1961) The birds of British Somaliland and the Gulf of Aden. Vol. III, p. 802. Edinburgh: Oliver and Boyd.

Benson C. W. and Benson, F. M. (1977) The birds of Malawi. Limbe: Montfort Press.

Borrett, R. (1967) Short notes: The Ground Hornbill in Inyanga. Honeyguide 52: 23.

Brooke, R. K. (1984) South African Red Data Book - birds. South African National Scientific Programmes Report No. 97. Pretoria: Foundation for Research and Development, CSIR.

Chiweshe, N. (1994) A comparison of Ground Hornbill B. leadbeateri, group sizes between protected areas, commercial farms and communal lands in Zimbabwe. The Farmer 64: 28-29.

Hustler, K., Solomon, D. and de la Harpe, D. (1990) Ground Hornbill, B. leadbeateri. Honeyguide 36: 11-17.

Irwin, M. P. S. (1981) The birds of Zimbabwe. Salisbury: Quest.

Kemp, A. (1976) Factors affecting the onset of breeding in African hornbills. Pp. 248-257 in Proceedings of the 16th International Ornithological Congress.

Kemp, A. (1987) Ground Hornbill under pressure in South Africa. Afr. Wildl. 41: 293.

Kemp, A. (1988) The behavioural ecology of the Southern Ground Hornbill: are competitive offspring at a premium? Pp. 267-271 in Proceedings of International 1ooth DOG meeting, Current topics in avian biology. Bonn: DOG.

Kemp, A. (1994). Ground Hornbill, the genus Bucorvus. Bull. Afr. Bird Club 1: 10-11.

Kemp, A. C. (1995) The hornbills: Bucerotiformes. Oxford: Oxford University Press.

Kemp, A. C. (2000a) Southern Ground Hornbill. Pp. 117-119 in K. N. Barnes, ed. The Eskom Red Data Book of birds of South Africa, Lesotho and Swaziland. Johannesburg: BirdLife South Africa.

Kemp, A. C. (20oob) The sustainable utilisation of birds: I. Emu 100: 355-365.

Kemp, A. and Kemp, M. I. (1980) The biology of the Southern African Ground Hornbill Bucorvus leadbeateri (Vigors) (Aves: Bucerotidae). Ann. Transvaal Mus. 32: 65-100.

Kemp, A. C., Joubert, C. S. J. and Kemp, M. I. (1989) Distribution of Southern Ground Hornbills in the Kruger National Park in relation to some environmental features. South Afr. J. Wildl. Res. 19: 93-98.

Knight, G..M. (1990) Status, distribution and foraging ecology of the Southern Ground Hornbill (Bucorous cafer) in Natal. Unpublished M.Sc. thesis. Durban: University of Natal.

Lorber, P. (1982) The Southern African Ground Hornbill as a montane bird. Honeyguide 111/112: $54-55$.

Maclean, G. L. (1993) Robert's birds of southern Africa. Cape Town: John Voelcker Book Fund. 
Magwizi, B. (2000) Ground Hornbill family accompanied by two juveniles. Honeyguide 46: 48.

Manson, C. and Tree, A. J. (1983) Short notes: The Ground Hornbill in the Vumba. Honeyguide 114/115: 54.

Msimanga, A. (2000) The role of birds in the culture of the Ndebele people of Zimbabwe. Ostrich 71: 22-24.

Reeson, A., Malcom, A. and Usherwood, J. (1994) Preliminary report of the 1994 Oxford University expedition to Zimbabwe. Unpublished report. Oxford: Oxford University.

Vernon, C. J. and Herremans, M. (1997) Ground Hornbill, Bucorvus leadbeateri. Pp. 708-709 in J. A. Harrison, D. G. Allan, L. G. Underhill, M. Herremans, A. J. Tree, V. Parker and C. J. Brown, eds. Atlas of Southern African birds. Vol. 1: Non-passerines. Johannesburg: BirdLife South Africa.

A. MSIMANGA

The Natural History Museum, P.O. Box 240, Bulawayo, Zimbabwe (e-mail: orni@telconet.co.zw) 